\title{
Clinical drug-drug interactions in patients admitted to hospital with COVID-19: high risk drug combinations, predictors, and
}

\section{management}

\author{
Amir Ali Mahboobipour ${ }^{1}$ and Shadi Baniasadi ${ }^{2}$ \\ ${ }^{1}$ Tehran University of Medical Sciences School of Medicine \\ ${ }^{2}$ National Research Institute of Tuberculosis and Lung Disease
}

May 29, 2020

\begin{abstract}
Aim: Coronavirus disease 2019 (COVID-19) is an emerging infectious disease that has no approved treatment. There are some medications which may be prescribed for COVID-19 patients as investigational treatments. Drug-drug interactions (DDIs) of medications used in treating COVID-19 is an important issue to be studied. Current study aimed to evaluate potential DDIs (pDDIs) and their predictors in hospitalized COVID-19 patients. Methods: A retrospective chart review study was conducted in a tertiary respiratory hospital dedicated for COVID-19 patients. Interacting drug combinations, severity, reliability, mechanism, and clinical management of pDDIs in confirmed COVID-19 cases were identified using the Lexi-Interact database. Logistic regression was applied to assess the correlation between occurrence of severe interactions and probable risk factors. Results: Two hundred and twenty-seven patients' medical charts were evaluated. About $68 \%$ of the patients had at least one comorbidity. The most common comorbidity was hypertension (30.4\%), followed by obesity (27.8\%) and diabetes (23.8\%). At least one major or contraindicated interaction was detected in $37.9 \%$ of the patients. Above $50 \%$ of the interactions were between lopinavir/ritonavir (protease inhibitor) and commonly prescribed medications (e.g. atorvastatin, alprazolam, salmeterol, and tamsulosin) for management of comorbidities or COVID-19 symptoms. Logistic regression analysis demonstrated that two comorbidities (IHD and CRDs) and ICU admission are significantly associated with occurrence of major or contraindicated pDDIs. Conclusion: The frequency of pDDIs is relatively high in COVID-19 patients. Patients receiving a protease inhibitor and having comorbidity or critical conditions should be monitored carefully in terms of DDIs.
\end{abstract}

\section{Introduction}

The coronavirus disease 2019 (COVID-19) is an infectious disease caused by severe acute respiratory syndrome coronavirus 2 (SARS-CoV-2). It was characterized as a pandemic by the World Health Organization (WHO) on 11 March 2020 [1]. Although the disease is not severe in most patients [2], it may progress to a serious illness and hospitalization particularly in the elderly and those with underlying medical problems like cardiovascular diseases, diabetes, chronic respiratory diseases, and cancer [3].

There is not yet any approved drug or vaccine to treat COVID-19 and treatment is principally supportive [4]. However, medications approved for other viral diseases such as Ebola, HIV and influenza are being experimentally applied against COVID-19 [5,6]. The WHO recommends to include confirmed cases of COVD-19 to a global clinical trial (SOLIDARITY) in which patients receive standard care or one of four recommended treatments. The treatment arms in SOLIDARITY are remdesivir, chloroquine or hydroxychloroquine, lopinavir/ritonavir, or lopinavir/ritonavir plus interferon beta-1a [7]. These regimens specifically those which include HIV protease inhibitors, may have complex drug-drug interactions (DDIs).

Besides WHO-recommended treatments, some other medications are being investigated as probable effective 
therapies against COVID-19. It is estimated that as many as 800 clinical trials are being planned or performed worldwide [5]. Meanwhile the scientists and clinicians are evaluating different therapies in order to discover the most effective treatments for COVID-19, they should also consider developing data on potential adverse effects and DDIs [8]. Because the medications for management of the wide spectrum of clinical symptoms of COVID-19 and/or underlying medical comorbidities may interact with the main treatments [9]. Some charts have been developed to predict drug interactions between experimental COVID-19 therapies and other medications [10]. However, data on potential DDIs (pDDIs) in COVID-19 patients in real practice is not available. We designed current study to investigate pDDIs and their predictors in hospitalized COVID-19 patients by reviewing their medical charts.

\section{Material and methods}

\section{Study design, setting, and participants}

This retrospective cross sectional study was carried out in Masih Daneshvari hospital, a respiratory center dedicated for COVID-19 patients in Tehran, Iran. COVID-19 patients admitted to the hospital from March 12-26, 2020 were enrolled to the study. COVID-19 cases were confirmed by polymerase chain reaction (PCR) test according to WHO case definition [1]. The study protocol was approved by ethical review board of national research institute of tuberculosis and lung diseases. Written informed consent by the patients was waived due to the retrospective nature of the investigation.

\section{Data collection}

The data were collected from the medical records of enrolled patients. Age, gender, body mass index (BMI), past medical history, length of hospital stay, intensive care unit (ICU) admission (directly or after admission to the ward), patients' outcome (discharge or death), and the medications prescribed during $24-48 \mathrm{~h}$ of hospital admission were gathered. Patients who stayed in the hospital for less then $48 \mathrm{~h}$ were excluded. The Lexi-Interact database (Lexicompß), Wolters Kluwer, Hudson, Ohio, United States, available on UpToDate, 2020) was applied to assess pDDIs. Based on the severity, the interactions were categorized into five categories including A (unknown), B (minor), C (moderate), D (major), and X (contraindicated) [11]. The reliability of the interactions was scaled as excellent $(\mathrm{E}=$ the interaction has been clearly demonstrated in well-controlled studies), good ( $\mathrm{G}=$ the studies strongly suggest that interaction exists; however, the proof of well-controlled studies is lacking), and fair ( $\mathrm{F}=$ available evidence is poor, but clinicians suspect interaction on the basis of pharmacologic considerations; or, evidence is good for an interaction of pharmacologically similar drug) $[12,13]$.

\section{Data analysis}

Data were entered into Statistical Package for Social Science version 22.0 (SPSS 22.0) for Windows (SPSS, Chicago, IL, USA). Both descriptive and analytical analysis were performed on the data. Due to low clinical importance of interactions with severity ratings of $\mathrm{A}, \mathrm{B}$, and $\mathrm{C}$, only interactions with $\mathrm{D}$ (major) and $\mathrm{X}$ (contraindicated) scales were considered for further analysis. The interacting drugs, documentation rate, mechanism of interaction, and clinical recommendations for prevention were recorded. Descriptive analyses of the variables were expressed as mean, standard deviation [SD], median, interquartile range [IQR], and percentage as appropriate.

The association between occurrence of pDDIs and probable risk factors were assessed using logistic regression analysis. Dependent variable was defined as exposure to at least one major or contraindicated pDDI. Patient's sex, common comorbidities (hypertension, obesity, diabetes, Ischemic Heart Disease (IHD), Chronic Respiratory Diseases (CRDs), neoplasms), and ICU admission were taken as the covariates. At the first, univariate logistic regression analysis was carried out. Variables with a significant univariate p-value $(<0.05)$ were further assessed by multivariate analysis.

\section{Results}

Demographics and clinical presentation 
Two hundred and sixty-two medical charts of patients with confirmed COVID-19 were evaluated. Thirty-five patients were excluded due to the length of hospital stay (less than $24 \mathrm{~h}$ ). Table 1 shows the demographic and clinical characteristics of the patients. Of total study population, $60.8 \%$ were male. A median number of 8 medications (IQR, 6-9) were administered for the patients during $24-48 \mathrm{~h}$ of hospital admission. About $68 \%$ of the patients had at least one comorbidity. The most common comorbidity was hypertension (30.4\%), followed by obesity $(27.8 \%)$ and diabetes $(23.8 \%)$.

\section{Drug-drug interactions}

Figure 1 shows the number of pDDIs in each category and exposed patients. Interactions with severity scale of $\mathrm{D}$ and $\mathrm{X}$ were $17.8 \%$ of total pDDIs (161 of 904 ). About $38 \%$ of the patients ( 86 of 227 ) were exposed to at least one $\mathrm{D}$ or $\mathrm{X}$ interaction.

Drug combinations, frequency, reliability, mechanism, and applicable recommendations for $\mathrm{D}$ and $\mathrm{X}$ interactions are shown in table 2 and 3, respectively. Of the total pDDIs with severity scale of D and X, 23.6\% were unique drug pairs (the interaction occurred one time) (appendix 1). The most frequent interactions were between lopinavir/ritonavir and commonly used medications metabolized by cytochrome P450 3A4 (CYP3A4) such as atorvastatin and alprazolam in D category and salmeterol/fluticasone and tamsulosin in $\mathrm{X}$ category.

\section{Risk factors}

In univariate logistic regression analysis, the occurrence of major and contraindicated pDDIs was significantly associated with four comorbidities (hypertension, diabetes, IHD, CRDs) and ICU admission as an indicator of COVID-19 severity. Multivariate analysis showed the independent predictors of occurrence of pDDIs are IHD (OR:5.3, [95\% CI:2.0-14.1], P = 0.001), CRDs (OR:3.6, [95\% CI:1.1-12.1], P = 0.04), and ICU admission (OR:3.3, [95\% CI:1.6-7.1], $\mathrm{P}=0.002$ ) (table 4).

\section{Discussion}

Infection control measures and supportive cares are currently the main clinical management for COVID-19. However, some medications are being used based on the results of laboratory, animal and clinical studies [7]. The current study is the first to retrospectively identify severity, frequency, mechanism, and clinical management of pDDIs in hospitalized patients with COVID-19. We found that $37.9 \%$ of COVID-19 patients were exposed to at least one major or contraindicated pDDI during 24-48 h of hospital admission. More than half of pDDIs were occurred between lopinavir/ritonavir (branded as Kaletra or Aluvia) and medications metabolized by CYP3A4. Additive interactions between antiplatelets/nonsteroidal anti-inflammatory drugs (NSAIDs) and anticoagulants were the second common pDDI in COVID-19 patients.

Lopinavir, a protease inhibitor, is widely used for the treatment of HIV. It is combined with ritonavir, another protease inhibitor, which inhibits CYP3A4 enzyme and increases the half-life of lopinavir [14]. Lopinavir/ritonavir has activity against severe acute respiratory syndrome coronavirus (SARS-CoV) and middle east respiratory syndrome coronavirus (MERS-CoV) both in vitro and in animal models $[15,16]$. Recently, an open-label, randomized, phase 2 trial revealed efficacy and safety of lopinavir/ritonavir combined with interferon beta-1b and ribavirin in the treatment of hospitalized patients with COVID-19 [17]. Both lopinavir and ritonavir have important DDIs due to inhibition of CYP3A4. It is essential to identify commonly used medications in patients with COVID-19 which are metabolized with this enzyme and may have severe interactions with lopinavir/ritonavir.

Our results show that HMG-CoA reductase inhibitors (atorvastatin, rosuvastatin) are the most frequent interacting medications with lopinavir/ritonavir in our patients. Some studies showed that co-administration of different protease inhibitors with atorvastatin increased the area under the concentration-time curve (AUC) of atorvastatin from 1.7 to 9.4 folds (depending on the type of protease inhibitor). Reducing atorvastatin dose to $20 \mathrm{mg}$ /day and monitoring for signs and symptoms of its toxicity (myalgia, rhabdomyolysis, liver function test (LFT) abnormalities) should be taken into account when a protease inhibitor is used concomitantly [18]. However, differentiation between signs and symptoms of HMG-CoA reductase inhibitors toxicity and 
COVID-19 is challenging because myalgia and abnormal LFT can also be seen in patients with COVID-19 [9, 19]. Rosuvastatin also have the same interaction with protease inhibitors and its dose should not be exceeded than $10 \mathrm{mg} /$ day when co-administered with lopinavir/ritonavir [20]. Rhabdomyolysis is a serious consequence of this interaction which was reported in patients who received lopinavir/ritonavir with atorvastatin or rosuvastatin $[21,22]$.

Anxiolytic/hypnotic/sedative agents such as alprazolam, chlordiazpoxide and midazolam were administered in our patients. According to the Lexi-Interact database, interaction of alprazolam or midazolam with lopinavir/ritonavir is rated as good and excellent; respectively, in terms of reliability. Other benzodiazpine agents that are less expected to interact with protease inhibitors (e.g. lorazepam, oxazepam, temazepam) can be administered instead of alprazolam [23]. Severe prolonged sedation and increased length of hospital stay were reported among patients receiving a combination of a protease inhibitor and intravenous midazolam [24]. Therefore, this interaction is categorized as contraindicated in terms of severity rating [25]. However, clinical outcomes of HIV patients (on protease inhibitors regimen) who received intravenous midazolam for procedural sedation and those who received diazepam were similar [26]. This combination should be administered with caution and reduced doses of intravenous midazolam should be considered [25].

SARS-CoV-2 may affect cardiovascular system and lead to myocardial injury, acute heart failure, or worsening pre-existing cardiovascular disease [27]. Therefore, interaction of cardiovascular agents with investigational medications for COVID-19 should be mentioned. In the current study, nondihydropyridine calcium channel blockers (diltiazem), cardiac glycosides (digoxin), antiarrhythmic agents (amiodarone, lidocaine), and isosorbide dinitrate had major or contraindicated interactions with lopinavir/ritonavir. Metabolism inhibition of nondihydropyridine calcium channel blockers can lead to increase their serum concentration and the risk of AV nodal blockade. Monitoring the toxicity of calcium channel blockers and a 50\% dose reduction of diltiazem may be required [28]. The mechanism of major interaction between lopinavir/ritonavir and digoxin is probably due to inhibition of P-glycoprotein transporter and reduction of digoxin renal clearance by ritonavir [29]. Reducing digoxin dose $(30 \%$ to $50 \%)$ or dosing frequency as well as monitoring digoxin levels is recommended [30]. Lopinavir/ritonavir may enhance the serum concentration of amiodarone and subsequently its QTc-prolonging effect. This combination should be avoided when possible, if not, a dose reduction and serial ECG monitoring is recommended [31]. Combination of amiodarone and azithromycin should also be cautioned in COVID-19 patients due to QTc prolongation synergism effect. Our previous study showed that DDIs are risk factor for prolonging QTc in ICU admitted patients [32]. Nevertheless, the interaction between hydroxychloroquine and azithromycin, two medications with QTc prolongation effect co-administered in some COVID-19 patients, is graded as minor (B) interaction [33]. For B interactions, no intervention is needed according to the Lexi-Interact database but calculating the risk score of QTc prolongation before administration of this combination to COVID-19 patients is a wisely measure.

Excessive inflammation, platelet activation, endothelial dysfunction, and stasis may lead to arterial and venous thrombotic disease in COVID-19 patients [34]. Drug interactions of common anticoagulants should be considered in these patients. In the current study apixaban and rivaroxaban were administered to the patients. Among novel oral anticoagulants (NOACs), apixaban and rivaroxaban are substrates for both Pglycoprotein transporter and CYP3A4. Therefore, concomitant administration with inhibitors of CYP3A4 and P-glycoprotein transporter (e.g. lopinavir/ritonavir) should be avoided due to increased serum concentration of apixaban and rivaroxaban and risk of bleeding [35].

Additionally, co-administration of antiplatelets or NSAIDs with anticoagulants may increase the risk of bleeding [36]. Because of underlying cardiovascular diseases in some COVID-19 patients, they may regularly use antiplatelet agents. NSAIDs may also be prescribed to relieve myalgia [37] or for their probable effect on SARS-CoV-2 (specifically indomethacin) [38]. Anticoagulants side effects should be monitored in COVID-19 patients receiving these combinations.

Administration of salmeterol or combination medications containing salmeterol may be indicated in COVID19 patients with underlying chronic respiratory diseases. Lopinavir/ritonavir increases serum concentration of salmeterol [39] and may predispose patients to cardiovascular adverse effects of beta2-agonists. 
Another important interaction that may occur in COVID-19 male patients with older age is between tamsulosin and lopinavir/ritonavir. Although the adverse consequences of this interaction has not been evaluated in the clinical studies, this combination is contraindicated according to the tamsulosin drug label [40]. When the combination must be used, monitoring tamsulosin adverse effects (particularly orthostatic hypotension) is recommended.

Logistic regression analysis confirmed that two comorbidities (IHD and CRDs) and ICU admission were significantly associated with occurrence of major and contraindicated pDDIs. Patients with IHD or CRDs may receive some medications which have severe interactions with investigational drugs for COVID-19 especially protease inhibitors. The current study shows other investigational medications including hydroxychloroquine, ribavirin, remdesivir, favipiravir, interferon beta or intravenous immunoglobulin do not interact with commonly used medications for comorbidities. Therefore, these medicines are much safer than protease inhibitors in terms of severe DDIs. We also found critically ill patients are more prone to DDIs because they have complicated conditions and receive more medications.

The first limitation of the current study is that it cannot predict the occurrence rate of actual DDIs. Because subjective and objective evidence for an actual DDI usually are not accurately recorded specifically during a critical pandemic condition and it is a limitation of the retrospective studies. These evidence can be collected with a prospective study in order to report actual DDIs. The second limitation is using one drug interaction database. Evaluating severity rating of some pDDIs with another drug interaction database (except LexiInteract) showed a little variation. It would be better to check the interactions with more than one database in order to report more accurate results.

\section{Conclusions}

Patients with COVID-19 may expose to many pDDIs but physicians should consider pros and cons of prescribing medications, severity and clinical consequences of the interactions, and probable outcomes in order to make the best decision. Choosing an alternative medication or adjusting dosage of interacting drugs can improve patients' management by both providing essential medications and preventing adverse drug effects.

\section{Acknowledgments}

We thank all health care workers of Masih Daneshvari hospital working at the front line against COVID-19. We also appreciate information technology and health records staff of the hospital for providing electronic health records.

Conflict of interest: There is no conflicting interest to be declared by the authors.

Funding: This study was funded by National Research Institute of Tuberculosis and Lung Diseases.Data availability: The data that support the findings of this study are available from the corresponding author upon reasonable request.

\section{References}

1. World Health Organization. Coronavirus disease 2019 (COVID-19) Situation Report - 51. March 2020. https://www.who.int/docs/default-source/coronaviruse/situation-reports/20200311-sitrep-51covid-19.pdf. Accessed May 21, 2020.

2. Yang W, Cao Q, Qin L, et al. Clinical characteristics and imaging manifestations of the 2019 novel coronavirus disease (COVID-19):A multi-center study in Wenzhou city, Zhejiang, China. J Infect. 2020; 80: 388-393.

3. People Who Are at Higher Risk for Severe Illness | Coronavirus | COVID-19 | CDC. https://www.cdc.gov/coronavirus/2019-ncov/need-extra-precautions/groups-at-higher-risk.html. Accessed May 21, 2020. 
4. Coronavirus Disease 2019 (COVID-19) Frequently Asked Questions | FDA. https://www.fda.gov/emergency-preparedness-and-response/coronavirus-disease-2019-covid19/coronavirus-disease-2019-covid-19-frequently-asked-questions. Accessed May 21, 2020.

5. Becker RC. Covid-19 treatment update: follow the scientific evidence. J Thromb Thrombolysis. 2020. [Epub ahead of print].

6. The hunt for an effective treatment for COVID-19| Feature | Pharmaceutical Journal. https://www.pharmaceutical-journal.com/news-and-analysis/features/the-hunt-for-an-effective-treatmentfor-covid-19/20207883.article?firstPass=false. Accessed May 21, 2020.

7. Solidarity clinical trial for COVID-19 treatments. https://www.who.int/emergencies/diseases/novelcoronavirus-2019/global-research-on-novel-coronavirus-2019-ncov/solidarity-clinical-trial-for-covid-19treatments. Accessed April 26, 2020.

8. Drug Interaction Concerns for COVID-19 Treatments | Clinical Drug Information. https://www.wolterskluwercdi.com/blog/drug-interaction-concerns-covid-19-treatments/. Accessed April $28,2020$.

9. Back D, Marzolini C, Hodge C, et al. COVID-19 treatment in patients with comorbidities: Awareness of drug-drug interaction. Br J Clin Pharmacol. [Epub ahead of print].

10. Liverpool COVID-19 Interactions. https://www.covid19-druginteractions.org/. Accessed April 28, 2020.

11. Lexi-Interact Data Fields. http://webstore.lexi.com/Information/Product-Information/Lexi-InteractFields. Accessed May 14, 2020.

12. Farzanegan B, Alehashem M, Bastani M, Baniasadi S. Potential drug-drug interactions in cardiothoracic intensive care unit of a pulmonary teaching hospital. J Clin Pharmacol. 2015; 55: 132-136.

13. Hassanzad M, Tashayoie Nejad S, Mahboobipour AA, Salem F, Baniasadi S. Potential drug-drug interactions in hospitalized pediatric patients with respiratory disorders: A retrospective review of clinically important interactions. Drug Metab Pers Ther. 2020: 35.

14. Croxtall JD, Perry CM. LopinavirRitonavir: A review of its use in the management of HIV-1 infection. Drugs. 2010; 70: 1885-1915.

15. Chu CM, Cheng VCC, Hung IFN, et al. Role of lopinavir/ritonavir in the treatment of SARS: Initial virological and clinical findings. Thorax. 2004; 59: 252-256.

16. Chan JFW, Yao Y, Yeung ML, et al. Treatment with lopinavir/ritonavir or interferon- $\beta 1 \mathrm{~b}$ improves outcome of MERSCoV infection in a nonhuman primate model of common marmoset. J Infect Dis. 2015; 212: 1904-1913.

17. Hung IF, Lung K, Tso EY, et al. Articles Triple combination of interferon beta-1b , lopinavir - ritonavir , and ribavirin in the treatment of patients admitted to hospital with COVID-19: an open-label, randomised , phase 2 trial. Lancet. 2020; 6736: 1-10.

18. Lopinavir and Ritonavir - Atorvastatin. Interactions. Lexicomp. Wolters Kluwer Health, Inc. Riverwoods, IL. Available at: http://online.lexi.com. Accessed April 302020.

19. Zhang C, Shi L, Wang FS. Liver injury in COVID-19: management and challenges. Lancet Gastroenterol Hepatol. 2020; 5: 428-430.

20. Lopinavir and Ritonavir - Rosuvastatin. Interactions. Lexicomp. Wolters Kluwer Health, Inc. Riverwoods, IL. Available at: http://online.lexi.com. Accessed April 302020.

21. Mah Ming JB, Gill MJ. Drug-induced rhabdomyolysis after concomitant use of clarithromycin, atorvastatin, and lopinavir/ritonavir in a patient with HIV. AIDS Patient Care STDS. 2003; 17: 207-210. 
22. De Kanter CT, Keuter M, Van Der Lee MJ, Koopmans PP, Burger DM. Rhabdomyolysis in an HIV-infected patient with impaired renal function concomitantly treated with rosuvastatin and lopinavir/ritonavir. Antivir Ther. 2011; 16: 435-437.

23. Lopinavir and Ritonavir - Alprazolam. Interactions. Lexicomp. Wolters Kluwer Health, Inc. Riverwoods, IL. Available at: http://online.lexi.com. Accessed April 302020.

24. Jenh Hsu A, Carson KA, Yung R, Paul A. Severe prolonged sedation associated with coadministration of protease inhibitors and intravenous midazolam during bronchoscopy. Pharmacotherapy. 2012; 32: 538-545.

25. Lopinavir and Ritonavir - Midazolam. Interactions. Lexicomp. Wolters Kluwer Health, Inc. Riverwoods, IL. Available at: http://online.lexi.com. Accessed April 302020.

26. Backman ES, Triant VA, Ehrenfeld JM, et al. Safety of midazolam for sedation of HIV-positive patients undergoing colonoscopy. HIV Med. 2013; 14: 379-384.

27. Clerkin KJ, Fried JA, Raikhelkar J, et al. Coronavirus Disease 2019 (COVID-19) and Cardiovascular Disease. Circulation. 2020. [Epub ahead of print].

28. Lopinavir and Ritonavir - Diltiazem. Interactions. Lexicomp. Wolters Kluwer Health, Inc. Riverwoods, IL. Available at: http://online.lexi.com. Accessed April 302020.

29. Kirby BJ, Collier AC, Kharasch ED, Whittington D, Thummel KE, Unadkat JD. Complex drug interactions of the HIV protease inhibitors 3: Effect of simultaneous or staggered dosing of digoxin and ritonavir, nelfinavir, rifampin, or bupropion. Drug Metab Dispos. 2012; 40: 610-616.

30. Lopinavir and Ritonavir - Digoxin. Interactions. Lexicomp. Wolters Kluwer Health, Inc. Riverwoods, IL. Available at: http://online.lexi.com. Accessed April 302020.

31. Lopinavir and Ritonavir - Amiodarone. Interactions. Lexicomp. Wolters Kluwer Health, Inc. Riverwoods, IL. Available at: http://online.lexi.com. Accessed April 302020.

32. Hosseinpoor Z, Farzanegan B, Seyyedi SR, Rajabi M, Baniasadi S. Drug interactions and creatinine levels are associated with QTc prolongation in intensive care units: A prospective, observational study. Drug Metab Pers Ther. 2019; 34 :2-8.

33. Hydroxychloroquine - Azithromycin. Interactions. Lexicomp. Wolters Kluwer Health, Inc. Riverwoods, IL. Available at: http://online.lexi.com. Accessed April 302020.

34. Bikdeli B, Madhavan MV, Jimenez D, et al. COVID-19 and thrombotic or thromboembolic disease: implications for prevention, antithrombotic therapy, and follow-up. J Am Coll Cardiol. 2020. [Epub ahead of print].

35. Vranckx P, Valgimigli M, Heidbuchel H. The significance of drug-drug and drug-food interactions of oral anticoagulation. Arrhythmia Electrophysiol Rev. 2018; 7: 55-61.

36. Delaney JA, Opatrny L, Brophy JM, Suissa S. Drug-drug interactions between antithrombotic medications and the risk of gastrointestinal bleeding. CMAJ. 2007;177:347-351.

37. Coronavirus disease 2019 (COVID-19) - Diagnosis and treatment - Mayo Clinic. https://www.mayoclinic.org/diseases-conditions/coronavirus/diagnosis-treatment/drc-20479976. Accessed May 21, 2020.

38. Amici C, Di Caro A, Ciucci A, et al. Indomethacin has a potent antiviral activity against SARS coronavirus. Antivir Ther. 2006; 11: 1021-1030.

39. Lopinavir and Ritonavir - Salmeterol. Interactions. Lexicomp. Wolters Kluwer Health, Inc. Riverwoods, IL. Available at: http://online.lexi.com. Accessed April 302020. 
40. Flomax (tamsulosin) [prescribing information]. https://www.accessdata.fda.gov/drugsatfda_docs/label/2009/020579s026lbl.pdf. Accessed May 21, 2020.

Table 1 Demographic and clinical characteristics of the patients

\begin{tabular}{ll}
\hline Study population & No. $(\%)$ \\
\hline Number of patients & 227 \\
Age, mean (SD), years & $57.7( \pm 15.0)$ \\
Hospital stay, median (IQR), days & $5(4-8)$ \\
Number of drugs, median (IQR) & $8(6-9)$ \\
Gender & $138(60.8 \%)$ \\
Male & $89(39.2 \%)$ \\
Female & $40(17.6 \%)$ \\
ICU admission (directly or after admission to the & \\
ward) & $21(9.3 \%)$ \\
Death & \\
Chief complaint & $35(15.4 \%)$ \\
Fever & $45(19.8 \%)$ \\
Cough & $128(56.4 \%)$ \\
Dyspnea & $19(8.4 \%)$ \\
Fatigue or myalgia & $154(67.8 \%)$ \\
Any comorbidity ${ }^{1}$ & $69(30.4 \%)$ \\
Hypertension & $63(27.8 \%)$ \\
Obesity (BMI[?]30) & $54(23.8 \%)$ \\
Diabetes & $31(13.7 \%)$ \\
Ischemic heart disease & $15(6.6 \%)$ \\
Chronic respiratory diseases (Asthma/COPD) & $10(4.4 \%)$ \\
Neoplasms & $9(4.0 \%)$ \\
Diseases of the genitourinary system & $8(3.5 \%)$ \\
Nervous system disease & $7(3.1 \%)$ \\
Other endocrine, nutritional and metabolic & $7(3.1 \%)$ \\
diseases & \\
Other diseases of the circulatory system ${ }^{3}$ & $5(2.2 \%)$ \\
Diseases of the musculoskeletal system and & $4(1.8 \%)$ \\
connective tissue & $3(1.3 \%)$ \\
Diseases of the blood and blood-forming organs and & $2(0.9 \%)$ \\
certain disorders involving the immune mechanism & $1(0.4 \%)$ \\
Mental and behavioural disorders & \\
Diseases of the digestive system & \\
Certain infectious and parasitic diseases & \\
\hline
\end{tabular}

${ }^{1}$ Uncommon comorbidities were classified according to the International Classification of Diseases by WHO (ICD-10).

${ }^{2}$ Not including diabetes and obesity.

${ }^{3}$ Not including hypertension and ischemic heart disease.

Table 2 Drug combinations, frequency, reliability, mechanism, and recommendations for major (D) interactions 


\begin{tabular}{|c|c|c|c|c|}
\hline $\begin{array}{l}\text { Drug } \\
\text { combination }\end{array}$ & No. & $\mathbf{R}^{1}$ & Mechanism/Effect & Recommendations \\
\hline $\begin{array}{l}\text { Lopinavir/Ritonavir } \\
+ \text { Atorvastatin }\end{array}$ & 32 & $\mathrm{~F}$ & $\begin{array}{l}\text { CYP3A4 } \\
\text { inhibitors }{ }^{2} \text { may } \\
\text { increase the } \\
\text { serum } \\
\text { concentration of } \\
\text { atorvastatin }\end{array}$ & $\begin{array}{l}\text { Start with the } \\
\text { lowest possible } \\
\text { atorvastatin dose, } \\
\text { monitor for signs } \\
\text { and symptoms of } \\
\text { toxicity }\end{array}$ \\
\hline $\begin{array}{l}\text { Aspirin }+ \\
\text { Enoxaparin }\end{array}$ & 13 & $\mathrm{~F}$ & $\begin{array}{l}\text { Antiplatelet } \\
\text { agents may } \\
\text { enhance the } \\
\text { anticoagulant } \\
\text { effect of } \\
\text { Enoxaparin }\end{array}$ & $\begin{array}{l}\text { Monitor closely } \\
\text { for signs and } \\
\text { symptoms of } \\
\text { bleeding }\end{array}$ \\
\hline $\begin{array}{l}\text { Lopinavir/Ritonavir } \\
+ \text { Alprazolam }\end{array}$ & 10 & $\mathrm{G}$ & $\begin{array}{l}\text { CYP3A4 } \\
\text { inhibitors may } \\
\text { increase the } \\
\text { serum } \\
\text { concentration of } \\
\text { alprazolam }\end{array}$ & $\begin{array}{l}\text { Consider using an } \\
\text { alternative }\end{array}$ \\
\hline $\begin{array}{l}\text { Clopidogrel + } \\
\text { Enoxaparin }\end{array}$ & 5 & $\mathrm{~F}$ & $\begin{array}{l}\text { Antiplatelet } \\
\text { agents may } \\
\text { enhance the } \\
\text { anticoagulant } \\
\text { effect of } \\
\text { enoxaparin }\end{array}$ & $\begin{array}{l}\text { Monitor closely } \\
\text { for signs and } \\
\text { symptoms of } \\
\text { bleeding }\end{array}$ \\
\hline $\begin{array}{l}\text { Lopinavir/Ritonavir } \\
\text { + Dexamethasone }\end{array}$ & 5 & $\mathrm{~F}$ & $\begin{array}{l}\text { CYP3A4 } \\
\text { inhibitors may } \\
\text { increase the } \\
\text { serum } \\
\text { concentration of } \\
\text { dexamethasone }\end{array}$ & $\begin{array}{l}\text { Monitor for } \\
\text { increased adverse } \\
\text { effects of } \\
\text { dexamethasone, } \\
\text { consider dose } \\
\text { reduction }\end{array}$ \\
\hline $\begin{array}{l}\text { Lopinavir/Ritonavir } \\
+ \text { Prednisolone }\end{array}$ & 5 & $\mathrm{~F}$ & $\begin{array}{l}\text { CYP3A4 } \\
\text { Inhibitors may } \\
\text { increase the } \\
\text { serum } \\
\text { concentration of } \\
\text { prednisolone }\end{array}$ & $\begin{array}{l}\text { Monitor for } \\
\text { increased adverse } \\
\text { effects of } \\
\text { prednisolone, } \\
\text { consider dose } \\
\text { reduction }\end{array}$ \\
\hline $\begin{array}{l}\text { Lopinavir/Ritonavir } \\
\text { + Rosuvastatin }\end{array}$ & 5 & $\mathrm{~F}$ & $\begin{array}{l}\text { CYP3A4 } \\
\text { Inhibitors may } \\
\text { increase the } \\
\text { serum } \\
\text { concentration of } \\
\text { rosuvastatin }\end{array}$ & $\begin{array}{l}\text { Start with the } \\
\text { lowest possible } \\
\text { rosuvastatin dose, } \\
\text { monitor for signs } \\
\text { and symptoms of } \\
\text { toxicity }\end{array}$ \\
\hline $\begin{array}{l}\text { Naproxen + } \\
\text { Enoxaparin }\end{array}$ & 4 & $\mathrm{~F}$ & $\begin{array}{l}\text { NSAIDs }^{3} \text { may } \\
\text { enhance the } \\
\text { anticoagulant } \\
\text { effect of } \\
\text { enoxaparin }\end{array}$ & $\begin{array}{l}\text { Monitor closely } \\
\text { for signs and } \\
\text { symptoms of } \\
\text { bleeding }\end{array}$ \\
\hline
\end{tabular}




\begin{tabular}{|c|c|c|c|c|}
\hline $\begin{array}{l}\text { Drug } \\
\text { combination }\end{array}$ & No. & $\mathbf{R}^{1}$ & Mechanism/Effect & Recommendations \\
\hline $\begin{array}{l}\text { Naproxen + } \\
\text { Heparin }\end{array}$ & 4 & $\mathrm{~F}$ & $\begin{array}{l}\text { NSAIDs may } \\
\text { enhance the } \\
\text { anticoagulant } \\
\text { effect of heparin }\end{array}$ & $\begin{array}{l}\text { Decrease the dose } \\
\text { of heparin or } \\
\text { NSAIDs }\end{array}$ \\
\hline $\begin{array}{l}\text { Ibuprofen + } \\
\text { Enoxaparin }\end{array}$ & 3 & $\mathrm{~F}$ & $\begin{array}{l}\text { NSAIDs may } \\
\text { enhance the } \\
\text { anticoagulant } \\
\text { effect of } \\
\text { enoxaparin }\end{array}$ & $\begin{array}{l}\text { Monitor closely } \\
\text { for signs and } \\
\text { symptoms of } \\
\text { bleeding }\end{array}$ \\
\hline $\begin{array}{l}\text { Indomethacin + } \\
\text { Heparin }\end{array}$ & 3 & $\mathrm{~F}$ & $\begin{array}{l}\text { NSAIDs may } \\
\text { enhance the } \\
\text { anticoagulant } \\
\text { effect of heparin }\end{array}$ & $\begin{array}{l}\text { Decrease the dose } \\
\text { of heparin or } \\
\text { NSAIDs }\end{array}$ \\
\hline $\begin{array}{l}\text { Lopinavir/Ritonavir } \\
+ \text { Fentanyl }\end{array}$ & 3 & $\mathrm{~F}$ & $\begin{array}{l}\text { CYP3A4 } \\
\text { inhibitors may } \\
\text { increase the } \\
\text { serum } \\
\text { concentration of } \\
\text { fentanyl }\end{array}$ & $\begin{array}{l}\text { Monitor for } \\
\text { increased adverse } \\
\text { effects of fentanyl, } \\
\text { consider dose } \\
\text { reduction }\end{array}$ \\
\hline $\begin{array}{l}\text { Lopinavir/Ritonavir } \\
+ \text { Quetiapine }\end{array}$ & 3 & $\mathrm{~F}$ & $\begin{array}{l}\text { CYP3A4 } \\
\text { inhibitors may } \\
\text { increase the } \\
\text { serum } \\
\text { concentration of } \\
\text { quetiapine }\end{array}$ & $\begin{array}{l}\text { Consider using an } \\
\text { alternative or } \\
\text { reduce the } \\
\text { quetiapine dose to } \\
\text { one-sixth of the } \\
\text { original dose }\end{array}$ \\
\hline $\begin{array}{l}\text { Carbamazepine }+ \\
\text { Lopinavir/Ritonavir }\end{array}$ & 2 & $\mathrm{~F}$ & $\begin{array}{l}\text { Carbamazepine may } \\
\text { decrease the serum } \\
\text { concentration of } \\
\text { lopinavir }\end{array}$ & $\begin{array}{l}\text { Use a twice daily } \\
\text { lopinavir/ritonavir } \\
\text { regimen, monitor } \\
\text { for reduced effect of } \\
\text { lopinavir/ritonavir }\end{array}$ \\
\hline $\begin{array}{l}\text { Clopidogrel + } \\
\text { Heparin }\end{array}$ & 2 & $\mathrm{~F}$ & $\begin{array}{l}\text { Antiplatelet } \\
\text { agents may } \\
\text { enhance the } \\
\text { anticoagulant } \\
\text { effect of heparin }\end{array}$ & $\begin{array}{l}\text { Decrease the dose } \\
\text { of heparin or } \\
\text { clopidogrel }\end{array}$ \\
\hline $\begin{array}{l}\text { Indomethacin + } \\
\text { Enoxaparin }\end{array}$ & 2 & $\mathrm{~F}$ & $\begin{array}{l}\text { NSAIDs may } \\
\text { enhance the } \\
\text { anticoagulant } \\
\text { effect of } \\
\text { enoxaparin }\end{array}$ & $\begin{array}{l}\text { Monitor closely } \\
\text { for signs and } \\
\text { symptoms of } \\
\text { bleeding }\end{array}$ \\
\hline $\begin{array}{l}\text { Midazolam + } \\
\text { Fentanyl }\end{array}$ & 2 & $\mathrm{~F}$ & $\begin{array}{l}\text { Increased CNS } \\
\text { depressant effects }\end{array}$ & $\begin{array}{l}\text { Close monitoring } \\
\text { for adverse effects }\end{array}$ \\
\hline $\begin{array}{l}\text { Propofol + } \\
\text { Fentanyl }\end{array}$ & 2 & $\mathrm{~F}$ & $\begin{array}{l}\text { Increase CNS } \\
\text { depressant effects }\end{array}$ & $\begin{array}{l}\text { Close monitoring } \\
\text { for adverse effects }\end{array}$ \\
\hline
\end{tabular}




\begin{tabular}{|c|c|c|c|c|}
\hline $\begin{array}{l}\text { Drug } \\
\text { combination }\end{array}$ & No. & $\mathbf{R}^{1}$ & Mechanism/Effect & Recommendations \\
\hline $\begin{array}{l}\text { Lopinavir/Ritonavir } \\
+ \\
\text { Chlordiazepoxide }\end{array}$ & 2 & $\mathrm{~F}$ & $\begin{array}{l}\text { CYP3A4 } \\
\text { inhibitors may } \\
\text { increase the } \\
\text { serum } \\
\text { concentration of } \\
\text { chlordiazpoxide }\end{array}$ & $\begin{array}{l}\text { Monitor for } \\
\text { increased adverse } \\
\text { effects of } \\
\text { chlordiazpoxide }\end{array}$ \\
\hline $\begin{array}{l}\text { Lopinavir/Ritonavir } \\
\text { + Digoxin }\end{array}$ & 2 & G & $\begin{array}{l}\text { Ritonavir may } \\
\text { increase the } \\
\text { serum } \\
\text { concentration of } \\
\text { digoxin }\end{array}$ & $\begin{array}{l}\text { Reduce the } \\
\text { digoxin dose }(30 \% \\
\text { to } 50 \%) \text { or the } \\
\text { dosing frequency, } \\
\text { Monitor digoxin } \\
\text { levels }\end{array}$ \\
\hline $\begin{array}{l}\text { Lopinavir/Ritonavir } \\
+ \text { Oxycodone }\end{array}$ & 2 & $\mathrm{~F}$ & $\begin{array}{l}\text { CYP3A4 } \\
\text { inhibitors may } \\
\text { increase the } \\
\text { serum } \\
\text { concentration of } \\
\text { oxycodone }\end{array}$ & $\begin{array}{l}\text { Monitor for } \\
\text { increased adverse } \\
\text { effects of } \\
\text { oxycodone }\end{array}$ \\
\hline
\end{tabular}

${ }^{1}$ Reliability (R) was scaled as excellent (E), good (G), and fair (F).

${ }^{2}$ Lopinavir/ritonavir is a strong inhibitor of CYP3A4.

${ }^{3}$ Nonsteroidal anti-inflammatory drugs.

Unique drug pairs have been shown in appendix 1.

Table 3 Drug combinations, frequency, reliability, mechanism, and recommendations for contraindicated (X) interactions

\begin{tabular}{lllll}
\hline Drug combination & No. & $\mathbf{R}^{\mathbf{1}}$ & Mechanism/Effect \\
\hline Lopinavir/Ritonavir + Fluticasone/Salmeterol & 7 & $\mathrm{~F}$ & CYP3A4 inhibitors ${ }^{2}$ may increase the serum concentratio \\
Lopinavir/Ritonavir + Tamsulosin & 4 & G & CYP3A4 Inhibitors may increase the serum concentratior \\
Ipratropium Bromide/Salbutamol + Promethazine & 2 & F & Increase the anticholinergic effects \\
Lopinavir/Ritonavir + Midazolam & 2 & E & Protease Inhibitors may increase the serum concentration \\
\hline
\end{tabular}

${ }^{1}$ Reliability (R) was scaled as excellent $(\mathrm{E})$, good $(\mathrm{G})$, and fair $(\mathrm{F})$.

${ }^{2}$ Lopinavir/ritonavir is a strong inhibitor of CYP3A4.

Unique drug pairs have been shown in appendix 1.

Table 4 Logistic regression analysis for the risk factors of DDIs (D or X)

\begin{tabular}{lllll}
\hline Variable & Univariate analysis & Univariate analysis & Multivariate analysis & Multivariate analysis \\
\hline Sex & OR $(95 \% \mathrm{CI})$ & $\mathrm{p}$ value & OR $(95 \% \mathrm{CI})$ & $\mathrm{p}$ value \\
$\begin{array}{l}\text { Male } \\
\text { Female }\end{array}$ & $0.9(0.5-1.6)$ & 0.72 & - & - \\
Comorbidity & & & &
\end{tabular}




\begin{tabular}{lllll}
\hline Variable & Univariate analysis & Univariate analysis & Multivariate analysis & Multivariate analysis \\
\hline Hypertension & $3.7(2.0-6.6)$ & $<0.01$ & $1.9(0.9-3.8)$ & 0.08 \\
Obesity & $1.4(0.7-2.6)$ & 0.31 & - & - \\
Diabetes & $2.6(1.4-4.9)$ & $<0.01$ & $1.6(0.8-3.4)$ & 0.19 \\
IHD $^{1}$ & $7.4(3.0-18.1)$ & $<0.01$ & $5.3(2.0-14.1)$ & $<0.01$ \\
CRDs $^{2}$ & $3.6(1.2-10.9)$ & 0.02 & $3.6(1.1-12.1)$ & 0.04 \\
Neoplasms & $2.6(0.7-9.4)$ & 0.15 & - & - \\
ICU admission & & & $3.3(1.6-7.1)$ & $<0.01$ \\
Yes & $3.0(1.5-6.1)$ & $<0.01$ & & \\
No & & & & \\
\hline
\end{tabular}

Variables with univariate $\mathrm{p}$ values of less than 0.05 were included in multivariate analysis.

${ }^{1}$ Ischemic heart disease.

${ }^{2}$ Chronic respiratory diseases.

\section{Figure legend}

Figure 1: Number of potential drug-drug interactions (pDDIs) in different severity categories (A, B, C, D, $\mathrm{X}$ ) and number of patients exposed to each category.

Appendix 1 Drug combinations, frequency, reliability, mechanism, and recommendations for unique drug pairs interactions

\begin{tabular}{|c|c|c|c|}
\hline Drug combination & $\mathbf{S}^{1}$ & $\mathbf{R}^{2}$ & Mechanism/Effect \\
\hline Apixaban + Enoxaparin & $\mathrm{X}$ & $\mathrm{F}$ & Apixaban may enhance the anticoagulant effect of enoxaparir \\
\hline Carvedilol + Ipratropium Bromide/Salbutamol & $\mathrm{X}$ & $\mathrm{F}$ & Beta-blockers (nonselective) may diminish the bronchodilator \\
\hline Clarithromycin + Lopinavir/Ritonavir & $\mathrm{X}$ & $\mathrm{F}$ & Clarithromycin may increase the serum concentration of lopin \\
\hline Ipratropium Bromide + Diphenhydramine & $\mathrm{X}$ & $\mathrm{F}$ & Increase the anticholinergic effects \\
\hline Lopinavir/Ritonavir + Amiodarone & $\mathrm{X}$ & $\mathrm{F}$ & CYP3A $4^{3}$ inhibitors may increase the serum concentration of \\
\hline Lopinavir/Ritonavir + Rivaroxaban & $\mathrm{X}$ & $\mathrm{G}$ & P-glycoprotein and CYP3A4 inhibitors may increase the serur \\
\hline Rifampin + Lopinavir/Ritonavir & $\mathrm{X}$ & $\mathrm{G}$ & Rifampin may decrease the serum concentration of lopinavir/1 \\
\hline Salmetrol + Fluticasone /Salmeterol & $\mathrm{X}$ & $\mathrm{F}$ & Synergism effects of beta2-agonists (long-acting) \\
\hline Sertraline + Selegiline & $\mathrm{X}$ & $\mathrm{F}$ & Selective serotonin reuptake inhibitors may enhance the sero \\
\hline Amiodarone + Azithromycin & $\mathrm{D}$ & $\mathrm{F}$ & Increase QT-prolongation effects \\
\hline Amiodarone + Digoxin & $\mathrm{D}$ & $\mathrm{E}$ & Amiodarone may increase the serum concentration of digoxin \\
\hline Alprazolam + Oxycodone & $\mathrm{D}$ & $\mathrm{F}$ & Increase CNS depressant effects \\
\hline Atracurium + Dexamethasone & $\mathrm{D}$ & $\mathrm{E}$ & Neuromuscular-blocking agents (nondepolarizing) may enha \\
\hline Atracurium + Hydrocortisone & $\mathrm{D}$ & $\mathrm{E}$ & Neuromuscular-blocking agents (nondepolarizing) may enha \\
\hline Calcium Carbonate + Levofloxacin & $\mathrm{D}$ & $\mathrm{E}$ & Oral calcium salts may decrease the absorption of oral quino \\
\hline Calcium Carbonate + Levothyroxine & $\mathrm{D}$ & $\mathrm{F}$ & Oral calcium salts may decrease the absorption of thyroid p \\
\hline Carbamazepine + Alprazolam & $\mathrm{D}$ & $\mathrm{F}$ & CYP3A4 inducers may decrease the serum concentration of al \\
\hline Celecoxib + Enoxaparin & $\mathrm{D}$ & $\mathrm{F}$ & NSAIDs ${ }^{4}$ may enhance the anticoagulant effect of enoxaparin \\
\hline Citalopram + Enoxaparin & $\mathrm{D}$ & $\mathrm{F}$ & Agents with antiplatelet effects may enhance the anticoagulan \\
\hline Citalopram + Heparin & $\mathrm{D}$ & $\mathrm{F}$ & Antiplatelet agents may enhance the anticoagulant effect of 1 \\
\hline Citalopram + Ibuprofen & $\mathrm{D}$ & G & Selective serotonin reuptake inhibitors may enhance the anti \\
\hline Chlorpromazine + Azithromycin & $\mathrm{D}$ & $\mathrm{F}$ & Increase QT-prolongation effect \\
\hline Diltiazem + Atorvastatin & $\mathrm{D}$ & $\mathrm{F}$ & Diltiazem may increase the serum concentration of atorvasta \\
\hline Fluvoxamine + Heparin & $\mathrm{D}$ & $\mathrm{F}$ & Agents with antiplatelet effects may enhance the anticoagule \\
\hline Lopinavir/Ritonavir + Apixaban & $\mathrm{D}$ & $\mathrm{G}$ & P-glycoprotein and CYP3A4 inhibitors may increase the ser \\
\hline Lopinavir/Ritonavir + Colchicine & $\mathrm{D}$ & G & P-glycoprotein and CYP3A4 inhibitors may increase the ser \\
\hline
\end{tabular}




\begin{tabular}{llll}
\hline Drug combination & $\mathbf{S}^{\mathbf{1}}$ & $\mathbf{R}^{\mathbf{2}}$ & Mechanism/Effect \\
\hline Lopinavir/Ritonavir + Diltiazem & D & G & CYP3A4 inhibitors may increase the serum concentration of d \\
Lopinavir/Ritonavir + Isosorbide Dinitrate & D & F & CYP3A4 inhibitors may increase the serum concentration of is \\
Lopinavir/Ritonavir + Lidocaine & D & F & CYP3A4 inhibitors may increase the serum concentration of li \\
Morphine + Clopidogrel & D & F & Morphine may decrease the serum concentration of antiplatele \\
Morphine + Fentanyl & D & F & Increase CNS depressant effects \\
Midazolam + Morphine & D & F & Increase CNS depressant effects \\
Rifampin + Clarithromycin & D & G & CYP3A4 inducers may decrease the serum concentration of cle \\
Propofol + Morphine & D & F & Increase CNS depressant effects \\
Rifampin + Pantoprazole & D & F & CYP2C19 inducers may decrease the serum concentration pan \\
\hline
\end{tabular}

${ }^{1}$ Severity (S) was scaled as major (D) and contraindicated (X).

${ }^{2}$ Reliability (R) was scaled as excellent (E), good (G), and fair (F).

${ }^{3}$ Lopinavir/ritonavir is a strong inhibitor of CYP3A4.

${ }^{4}$ Nonsteroidal anti-inflammatory drugs.

\section{Hosted file}

Figure 1.docx available at https://authorea.com/users/327734/articles/455174-clinicaldrug-drug-interactions-in-patients-admitted-to-hospital-with-covid-19-high-risk-drugcombinations-predictors-and-management 